\title{
Genetic Cholesteryl Ester Transfer Protein Deficiency Caused by Two Prevalent Mutations as a Major Determinant of Increased Levels of High Density Lipoprotein Cholesterol
}

\author{
Akihiro Inazu, ${ }^{\star}$ Xian-Cheng Jiang, ${ }^{\ddagger}$ Tatsuo Haraki, ${ }^{\star}$ Kunimasa Yagi,, Nobuo Kamon, ${ }^{\star}$ Junji Koizumi,, Hiroshi Mabuchi, \\ Ryoyu Takeda, ${ }^{*}$ Koki Takata, ${ }^{\$}$ Yuri Moriyama," Mitsunori Doi," and Alan Tall* \\ *The Second Department of Internal Medicine, School of Medicine, Kanazawa University, Kanazawa 920, Japan; ${ }^{\ddagger}$ Division of Molecular \\ Medicine, Department of Medicine, Columbia University College of Physicians and Surgeons, New York 10032; ${ }^{8}$ Department of Internal \\ Medicine, Hiroshima Railway Hospital, Hiroshima 732, Japan; and "Kochi Prefectural Tosa-yamada Health Center, Kochi 782, Japan
}

\begin{abstract}
Genetic determinants of HDL cholesterol (HDL-C) levels in the general population are poorly understood. We previously described plasma cholesteryl ester transfer protein (CETP) deficiency due to an intron $14 \mathrm{G}(+1)$-to-A mutation(Int14 A) in several families with very high HDL-C levels in Japan. Subjects with HDL-C $\geq 100 \mathrm{mg} / \mathrm{dl}(n=130)$ were screened by PCR single strand conformational polymorphism analysis of the CETP gene. Two other mutations were identified by DNA sequencing or primer-mediated restriction map modification of PCR products: a novel intron 14 splice donor site mutation caused by $\mathbf{a}$ insertion at position +3 from the exon14/intron14 boundary (Int14 $T$ ) and a missense mutation (Asp ${ }^{442}$ to Gly) within exon 15 (D442G). The Int14 $\mathrm{T}$ mutation was only found in one family. However, the D442G and Int14 A mutations were highly prevalent in subjects with $\mathrm{HDL}-\mathrm{C} \geq 60 \mathrm{mg} / \mathrm{dl}$, with combined allele frequencies of $9 \%, 12 \%, 21 \%$, and $43 \%$ for HDLC 60-79, 80-99, 100-119, and $\geq 120 \mathrm{mg} / \mathrm{dl}$, respectively. Furthermore, prevalences of the D442G and Int14 A mutations were extremely high in a general sample of Japanese men $(n=236)$, with heterozygote frequencies of $7 \%$ and $2 \%$, respectively. These two mutations accounted for about $10 \%$ of the total variance of HDL-C in this population. The phenotype in a genetic compound heterozygote (Int14 $\mathrm{T}$ and Int14 A) was similar to that of Int14 A homozygotes (no detectable CETP and markedly increased HDL-C), indicating that the Int14 $\mathrm{T}$ produces a null allele. In four D442G homozygotes, mean HDL-C levels $(86 \pm 26 \mathrm{mg} / \mathrm{dl})$ were lower than in Int14 A homozygotes $(158 \pm 35 \mathrm{mg} / \mathrm{dl})$, reflecting residual CETP activity in plasma. In 47 D442G heterozygotes, mean HDL-C levels were $91 \pm 23 \mathrm{mg} / \mathrm{dl}$, similar to the level in D442G homozygotes, and significantly greater than mean HDL-C levels in Int14 A heterozygotes $(69 \pm 15 \mathrm{mg} / \mathrm{dl})$. Thus, the D442G mutation acts differently to the null mutations
\end{abstract}

\footnotetext{
A portion of this paper was presented at the Asian-Pacific Congress on coronary heart disease risk factor held in Hong Kong, January 1994.

Address correspondence to Akihiro Inazu, M.D., The Second Department of Internal Medicine, School of Medicine, Kanazawa University, Takara-machi 13-1, Kanazawa, 920, Japan.

Received for publication 6 April 1994 and in revised form 14 July 1994.
}

J. Clin. Invest.

(c) The American Society for Clinical Investigation, Inc. 0021-9738/94/11/1872/11 \$2.00

Volume 94, November 1994, 1872-1882 with weaker effects on HDL in the homozygous state and stronger effects in the heterozygotes, suggesting dominant expression of a partially defective allele. CETP deficiency, reflecting two prevalent mutations (D442G and Int14 A), is the first example of a genetic deficiency state which is sufficiently common to explain a significant fraction of the variation in HDL-C in the general population. (J. Clin. Invest. 1994. 94:1872-1882.) Key words: cholesteryl ester transfer protein deficiency - high density lipoprotein • hyper-alphalipoproteinemia $\cdot$ missense mutation • splice donor site mutation

\section{Introduction}

Most prospective epidemiologic studies have shown that increased levels of HDL cholesterol (HDL-C ${ }^{1}$ ) are an independent, negative risk factor for the development of coronary heart disease (CHD) (1). Recent recommendations of the Adult Treatment Panel II place increased emphasis on the importance of elevated $\mathrm{HDL}$, regarding $\mathrm{HDL}-\mathrm{C} \geq 60 \mathrm{mg} / \mathrm{dl}$ ( $1.55 \mathrm{mmol} / \mathrm{liter})$ as a beneficial factor that negates one positive $\mathrm{CHD}$ risk factor (2). HDL has a unique ability to facilitate cholesterol efflux from cells, including those within atherosclerotic lesions, and subsequently to transport excess cholesterol to the liver (3). There are several well-known environmental factors influencing HDL-C levels. Alcohol consumption, exercise, and female sex increase HDL-C levels. On the other hand, smoking, obesity, male sex, and diets high in polyunsaturated fat decrease HDL$C$ levels (4). These environmental factors often influence HDL levels through the activities of lipases or lipid transfer proteins $(4,5)$. Complex segregation analyses suggest no major gene determining HDL levels $(6,7)$; but in some recent studies, genetic factors appear to be determinants of HDL-C or apo AI levels in the general population (8-11). However, the putative genes involved have not been determined (6-11). In some families, cholesteryl ester transfer protein (CETP) deficiency or increased apo A-I production rate have been identified as genetic factors causing increased HDL-C levels $(12,13)$.

Plasma CETP mediates the transfer and exchange of cholesteryl ester (CE) and triglyceride (TG) between the plasma lipoproteins, and plays an important role in HDL-CE and apo A-I

1. Abbreviations used in this paper: CE, cholesteryl ester; CETP, cholesteryl ester transfer protein; $\mathrm{CHD}$, coronary heart disease; CV, coefficient of variation; D442G, Asp-to-Gly substitution at amino acid 442; FHALP, familial hyperalphalipoproteinemia; HDL-C, HDL cholesterol; Int14 A, intron $14 \mathrm{G}(+1)$-to-A; Int14 T, intron $14 \mathrm{~T}$ insertion(+3); SSCP, single-strand conformational polymorphism; TG, triglyceride. 
catabolism, and in the determination of HDL size and subclass distribution (14). In some primary and secondary hyperlipidemias (e.g., familial hypercholesterolemia, dysbetalipoproteinemia, hypertriglyceridemia, and nephrotic syndrome) and during postprandial lipemia, accelerated CETP-mediated CE transfer results in increased CE net mass transfer from HDL to VLDL or chylomicron, probably contributing to reduced HDL-CE levels and CE enrichment of potentially atherogenic chylomicron and VLDL remnants (14). Plasma CETP is a hydrophobic glycoprotein with 476 amino acids and $4 \mathrm{~N}$-linked glycosylation sites (15). The human CETP gene consists of 16 exons encompassing $25 \mathrm{kbp}$ on chromosome $16 \mathrm{q} 13$, near the lecithin:cholesterol acyltransferase and haptoglobin loci $(16,17)$. Plasma CETP mRNA is highly expressed in the liver as well as peripheral tissues such as spleen, adipose, and muscle $(18,19)$.

Human genetic CETP deficiency was originally identified as a splicing defect in Japanese subjects with very high HDL levels (12). The $G(+1)$-to-A transition at the intron 14 splice donor site results in a null allele: homozygotes with the mutation have no CETP in plasma and have marked elevation of HDLC $(12,20)$. Furthermore, genetic deficiency of CETP results in reduced CE contents in VLDL, intermediate density lipoprotein, and LDL, producing a potentially antiatherogenic lipoprotein profiles $(20,21)$. This mutant allele frequency is high in Japanese subjects with HDL-C levels $\geq 60 \mathrm{mg} / \mathrm{dl}$ ( $1.55 \mathrm{mmol} / \mathrm{liter})$ (22). In the present study, we report the phenotype and prevalence of other CETP gene mutations. One is a missense mutation in the carboxy terminal of CETP, which is the same nucleotide change as the mutation found in two cases with very high HDLC levels recently reported (23). The other is a novel splice donor site mutation caused by a single nucleotide insertion. Our studies reveal that the missense mutation has a distinctive phenotype and suggest that its prevalence is so high that it contributes to the upward skewing of the HDL-C distribution in a sample of the general Japanese population.

\section{Methods}

\section{Subjects}

To identify CETP gene mutations in Japanese subjects with high HDL levels (i.e., familial hyperalphalipoproteinemia [FHALP]), PCR single strand conformational polymorphism (SSCP) analysis was performed in 130 consecutive unrelated individuals with increased serum HDL-C levels $(\geq 100 \mathrm{mg} / \mathrm{dl})$ from several regions of Japan. We also screened for the known intron $14 \mathrm{G}(+1)$-to-A mutation (Int14 A) $(12,20,22)$. After the identification of mutations, screening studies were performed by PCR-based methods both in 130 unrelated subjects with HDL-C $\geq 100 \mathrm{mg} / \mathrm{dl}$ and 182 unrelated subjects with HDL-C $60-99 \mathrm{mg} / \mathrm{dl}$ attending the lipid clinic in Kanazawa University Hospital or the affiliated clinics in the Kanazawa district. After identification of probands, medical history, clinical data, and blood samples of family members were also obtained when possible. To determine the frequencies for CETP gene mutants in the general Japanese population, we analyzed the genotypes of 236 healthy Japanese men (age $47 \pm 9 \mathrm{yr}$, mean $\pm S D$; range, 25-69 yr of age) attending the medical clinic of HokurikuElectric Power Co. in Kanazawa for their annual health examinations. Information on age, cigarette smoking, alcohol consumption, and body mass index were obtained through questionnaire and interview. $1 \mathrm{U}$ of alcohol consumption was defined as $633 \mathrm{ml}$ of beer, $180 \mathrm{ml}$ of wine, $180 \mathrm{ml}$ of sake, or $70 \mathrm{ml}$ of hard liquor $(\sim 20-25 \mathrm{~g}$ ethanol). Lipid profiles, plasma CETP activity, and mass determinations were performed when subjects were not taking any lipid-lowering drugs. No medications were given unless otherwise noted in the text. Informed consent for all studies was obtained.
Four pedigrees with CETP deficiency are shown in Fig. 1. Kindred FHALP-464 contained individuals with both the Int14 A and intron 14 $\mathrm{T}$ insertion (+3) (Int14 T) mutations as well as a compound heterozygote. This family was from Hiroshima, and all members were healthy. Kindred FHALP-528 had a compound heterozygote with both the Aspto-Gly substitution at amino acid 442 (D442G) and Int14 A mutations. This family was from the rural area around Kanazawa. Family members were all healthy. In kindred FHALP-277, a male proband with mildly increased HDL levels was found to be heterozygous for the D442G mutation. He was found to have pulmonary sarcoidosis and vasospastic angina with a normal coronary angiogram. The diagnosis of vasospasm was established by an elevation of ST segments in leads II III and a VF induced by intracoronary ergonovine provocation test. He was treated with diltiazem $\mathrm{HCl}$. He had small bilateral xanthelasma. His lipid profiles were serum cholesterol $230 \pm 15 \mathrm{mg} / \mathrm{dl}(n=6$, coefficient of variation [CV] 6\%, and range $208-246 \mathrm{mg} / \mathrm{dl})$, LDL-C $134 \pm 10 \mathrm{mg} / \mathrm{dl}(n$ $=6, \mathrm{CV} 8 \%$, and range $115-142 \mathrm{mg} / \mathrm{dl})$, HDL-C $70 \pm 7 \mathrm{mg} / \mathrm{dl}(n=6$, CV $10 \%$, and range $64-84 \mathrm{mg} / \mathrm{dl})$, and triglyceride $133 \pm 59 \mathrm{mg} / \mathrm{dl}(n$ $=6, \mathrm{CV} 45 \%$, and range $82-227 \mathrm{mg} / \mathrm{dl}$ ). His healthy mother was found to be homozygous for the D442G mutation with mildly increased HDL$\mathrm{C}$ levels, 76 and $80 \mathrm{mg} / \mathrm{dl}$, on two different occasions. His mother was from southwest of Kanazawa. Other family members were healthy. In kindred FHALP-1084, a female proband was found to be a D442G homozygote. She and her family members were all healthy, except for her sibling (a homozygote) with chronic hepatitis caused by hepatitis $\mathrm{C}$ virus. The proband's father, an obligate heterozygote for the mutation, died of cerebral vascular attack of unknown cause. This family was from Kochi on the Shikoku Island.

\section{DNA analysis}

Single strand conformational polymorphism of PCR products. Genomic DNA was purified from white blood cells, and in vitro amplifications of genomic DNA were performed by PCR $(20,22)$. Oligonucleotide primers used for the amplification of exon 14 or 15 were based on published sequences $(15,16)$. Single-strand conformational polymorphism (SSCP) analyses of the amplified DNA were performed as described (24), with a slight modification (25). Briefly, $9 \mu$ l PCR products were incubated with $1 \mu \mathrm{l}$ of alkaline solution $(0.5 \mathrm{M}$ sodium hydroxide, $10 \mathrm{mM}$ EDTA) at $42^{\circ} \mathrm{C}$ for $5 \mathrm{~min}$, heat-denatured at $96^{\circ} \mathrm{C}$ for $3 \mathrm{~min}$, and loaded on $10-20 \%$ native (non-SDS) gradient polyacrylamide gel (Pagel; Atto Corp., Tokyo, Japan). The gels were run at $100 \mathrm{~V}$ for $10-$ $15 \mathrm{~h}$ at different conditions of $4^{\circ} \mathrm{C}$ and room temperature in $0.6 \times \mathrm{TBE}$

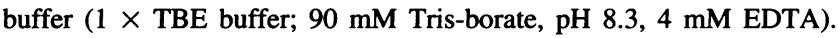
Single-stranded conformers were visualized with a silver-staining kit (Bio-Rad Laboratories, Richmond, CA). All PCR products were confirmed to be single bands resolved on agarose gel electrophoresis before performing SSCP analyses. Direct sequencing of double-strand DNA fragments of exon 14 and 15 were performed using internal sequencing primers and $T_{7}$ DNA polymerase (United State Biochemical Corp., Cleveland, $\mathrm{OH}$ ) as described elsewhere (12).

Primer-mediated restriction map modification for the diagnosis of point mutations. All mutagenic primers used for RFLP site-creating PCR assays were based on published sequences $(15,16)$ with specific nucleotide substitutions (oligonucleotide primer sequences for PCR, direct sequencing, and primer-mediated restriction map modifications are available from Dr. Inazu, if requested). Int14 A transition was performed with primer-mediated restriction map modifications of PCR products using primers of 14IA and 14IB29, and restriction enzyme NdeI (GIBCO BRL Life Technologies, Inc., Gaithersburg, MD) as described elsewhere (22). To confirm homozygosity for this mutation, a new RFLP sitecreating PCR assay using primers of 14IA and 14IBGT, and restriction enzyme Rsal was developed to recognize normal sequences (GTAN, +1 to +4 position; $N$, any nucleotide) in the splice donor site of intron 14. PCR products of the normal allele at this site generate a 138-bp fragment instead of 166-bp, after digestion of PCR products with $10 \mathrm{U}$ of RsaI (see Fig. 3). Methods to detect the two other point mutations were developed similarly. For the exon 15 missense mutation (an Ato-G transition: GAC/GGC), an Msp I site (5'-ccgg-3')-creating forward 
primer E15A and intron 15 reverse primer 15IB were used. Digestions of PCR products derived from the mutant allele with $10 \mathrm{U}$ of Msp I, gave rise to a 158-bp fragment instead of $179 \mathrm{bp}$ resolved on $3.5 \%$ NuSieve 3:1 agarose gel (FMC Corp. BioProducts, Rockland, ME) (see Fig. 2). To confirm homozygosity of the D442G mutation, a Sall site (5'-gtcgac-3')-creating PCR assay was also performed. Sall site-creating forward primer E15AA and 15IB were used to detect the normal sequence (NTCGAC) corresponding to amino acid 442 (see Fig. 2). For the detection of the intron $14+3$ position $T$ insertion, the 14IA foward primer and an HpaI site (5'-gttaac-3') creating reverse primer 14IB3T were used for the assay. The enzyme Hpal recognized the specific sequence (GTTAAN) in PCR products derived from the T-inserted allele, generating a 141-bp fragment instead of 166-bp (see Fig. 3).

\section{Analytical measurements}

Fasting plasma samples were isolated by clinical centrifuge within 30 min of venesection, and frozen at $-80^{\circ} \mathrm{C}$ until used for the activity assay. After measurements of CETP activity of plasma, the samples were shipped to Columbia University in a dry-ice package. Plasma CETP mass was determined by radioimmunoassay using ${ }^{125} \mathrm{I}$-labeled mAb TP2 (20). TP2 binding to the variant CETP of D442G was normal, because the epitope of TP2 is located between amino acids 463 and 475 (26).

${ }^{3} \mathrm{H}$-labeled $\mathrm{CE}$ containing $\mathrm{HDL}_{3}$ were prepared as described elsewhere (19). In brief, sonicated lipids were prepared with $250 \mu \mathrm{Ci}$ (sp act $74.0 \mathrm{Ci} / \mathrm{mmol}$ ) of ${ }^{3} \mathrm{H}$-labeled cholesteryl linoleate (NEN Research Products, Boston, MA), $4.66 \mu \mathrm{mol}$ fatty acid-free egg phosphatidylcholine (Sigma Chemical Co., St. Louis, MO), and $22 \mathrm{nmol}$ butylated hydroxytoluene. The labeled lipids were incubated with the $d>1.125 \mathrm{~g} /$ $\mathrm{ml}$ fraction of $50 \mathrm{ml}$ fresh serum in the presence of a lecithin:cholesterol acyltransferase inhibitor ( $1.4 \mathrm{mM}$ dithionitrobenzoic acid) for $16 \mathrm{~h}$ at $37^{\circ} \mathrm{C}$ under nitrogen gas. Labeled $\mathrm{HDL}_{3}(d=1.125-1.21 \mathrm{~g} / \mathrm{ml})$ was isolated by ultracentrifugation at $10^{\circ} \mathrm{C}$ in a $50.3 \mathrm{Ti}$ rotor (model L7-55; Beckman Instruments, Inc., Fullerton, CA). CETP activity was measured using ${ }^{3} \mathrm{H}$-labeled $\mathrm{CE}$ containing $\mathrm{HDL}_{3}$ as described elsewhere (27). In brief, $40 \mu \mathrm{l}$ of 10 -fold diluted plasma was used as a source of CETP. Unlabeled LDL ( $250 \mu \mathrm{g}$ cholesterol, $d=1.019-1.063 \mathrm{~g} / \mathrm{ml})$ and 20,000 dpm of ${ }^{3} \mathrm{H}$-labeled CE containing $\mathrm{HDL}_{3}(10-20 \mathrm{nmol}$ of $\mathrm{CE})$ were incubated in the presence of $1.4 \mathrm{mM}$ dithionitrobenzoic acid in $500 \mu \mathrm{l}$ of $50 \mathrm{mM}$ Tris- $\mathrm{HCl}, 150 \mathrm{mM} \mathrm{NaCl}, 2 \mathrm{mM}$ EDTA, pH 7.4 at $37^{\circ} \mathrm{C}$ for $3 \mathrm{~h}$ in a metabolic shaker. The reaction was stopped by chilling on ice for $30 \mathrm{~min}$. After the precipitation of LDL by the addition of a solution containing heparin-manganese chloride and BSA fraction V (final concentration; $1.3 \mathrm{mg} / \mathrm{dl}, 92 \mathrm{mM}$ and $4 \%$, respectively), the radioactivity in the HDL fraction was determined by liquid scintillation counting. These conditions gave stable and linear transfer of labeled CE, representing less than $30 \%$ transfer of the initial radioactivity. CETP activity measurements were performed in a triplicate assay and CETP specific activity was expressed as nmol CE transferred $\times(1 \mathrm{~h})^{-1} \times(1 \mu \mathrm{g}$ (ETP) $)^{-1}$.

Blood samples were obtained after a 12-h overnight fast. Serum cholesterol and triglyceride were determined enzymatically (TBA 20R; Toshiba, Tokyo, Japan) $(28,29)$. The concentrations of apo A-I, A-II, B, C-II, C-III, and E were determined by immunoturbidimetry as described (ApoAuto; Daiichi Chemical, Tokyo, Japan) (30). Intraassay and between assays $\mathrm{CV}$ for apolipoprotein measurements were less than $6 \%$. Serum HDL-C was determined by a heparin-calcium chloride precipitation method (20). This method was validated by comparison of values for HDL-C by the precipitation and preparative ultracentrifugation ( $d$ $=1.063-1.21 \mathrm{~g} / \mathrm{ml}$ ) in samples of increased HDL-C levels caused by hetero- or homozygous CETP deficiency ( $n=22$, HDL-C $47-230 \mathrm{mg}$ / dl). There was a good correlation $(r=0.986, P=0.001)$ between the two methods. However, there was a small difference $(\sim 8 \mathrm{mg} / \mathrm{dl} ; 95 \%$ CI, 4-12 mg/dl) between two methods (values by the ultracentrifugation minus the precipitation) in samples with HDL-C $<120 \mathrm{mg} / \mathrm{dl}$, and a $\sim 4-11 \%$ underestimation of the values by the precipitation method in samples with $\geq 120 \mathrm{mg} / \mathrm{dl}$. We have used only HDL-C values deter- mined by the precipitation method in this report. LDL cholesterol was calculated using the Friedewald formula (31).

\section{Statistical analysis}

All values were expressed as mean \pm SD. Multiple comparisons of lipoprotein levels among genotypes were made by Fisher's least significant difference only in variables whose $P$ values were less than 0.05 by the $F$-test in one-way ANOVA (32). 95\% CI for allele or heterozygote frequency were determined with $F$-distribution. For multiple regression analysis on serum HDL-C, the nominal variable (i.e., CETP genotype) was included as well as numerical variables (age, alcohol consumption, cigarette smoking, and body mass index). Heterozygous CETP deficiency was assigned a value of 1 for this variable, and normal CETP genotype is assigned a value of 0 . To bring distributions of measures closer to normality, raw values of body mass index and triglyceride were transformed by natural logarithm, and alcohol and cigarette consumptions were by square root of values. Genetic variance of serum HDL-C due to heterozygous CETP deficiency was determined as follows: $\left[2 p q\left(\mu_{1}-\mu\right)^{2}+p^{2}\left(\mu_{2}-\mu\right)^{2}\right] /$ total phenotypic variance of serum HDL-C; $q$, combined allele frequency for CETP deficiency; $p, 1-q$; $\mu, \mu_{1}$, and $\mu_{2}$ are means of serum HDL-C levels in all subjects, subjects with CETP deficiency, and subjects with non-CETP deficiency, respectively (33).

\section{Results}

To identify CETP gene mutations, we screened subjects with HDL-C $\geq 100 \mathrm{mg} / \mathrm{dl}$ using SSCP analyses of PCR products. All segments of 16 exons, and their flanking intronic sequences and promoter regions ( $~ 360 \mathrm{bp}$ ) were analyzed. Several variant conformers were identified in the regions of exon 14 and 15. These conformers were confirmed to have point mutations by direct sequencing of the PCR products. One mutation was a single-base A-to-G transition within exon 15 that changes the codon for amino acid 442 of CETP, resulting in replacement of the acidic residue aspartic acid (Asp) by the neutral residue glycine (Gly) (D44íG). Unrelated subjects with HDL-C $\geq 60$ $\mathrm{mg} / \mathrm{dl}(n=312)$ and their family members were screened for this mutation using an MspI site-creating PCR method (Fig. 2). Remarkably, 4 homozygotes, 49 heterozygotes, and 4 genetic compound heterozygotes with the D442G mutation were found. A Sall site-creating PCR method was used to confirm homozygosity of the mutation in subjects with the D442G mutation (Fig. 2). Three pedigrees of subjects with CETP deficiency involving the D442G mutation are shown (Fig. 1). Mildly to moderately increased HDL tended to segregate with the D442G mutation.

Another mutation was a novel intron 14 splice donor site mutation. This mutation was a single-nucleotide insertion of $\mathrm{T}$ at the +3 position of the intron 14 splice donor site (Int14 T). In the kindred of FHALP-464, this novel splice donor site mutation was identified in two generations as shown (Figs. 1 and 3). A daughter with no plasma CETP mass and activity, and serum HDL-C $106 \mathrm{mg} / \mathrm{dl}$, was found to be a genetic compound heterozygote with two different splice donor site mutations involving intron 14 (pedigree position III-2). The null phenotype in this subject indicates that the Int14 $\mathrm{T}$ is a null allele, as shown for the Int 14 A (20). Reduced CETP to $~ 59 \%$ of normal levels in the two Int14 T heterozygotes is also consistent with the Int14 T being a null allele. Serum HDL-C $127 \mathrm{mg} / \mathrm{dl}$ in the proband appeared higher than expected for a single null allele (20), suggesting involvement of other factors increasing HDL level. All subjects with HDL-C $\geq 60 \mathrm{mg} / \mathrm{dl}$ were screened for 


\section{Pedigree of FHALP464 - HIROSHIMA}

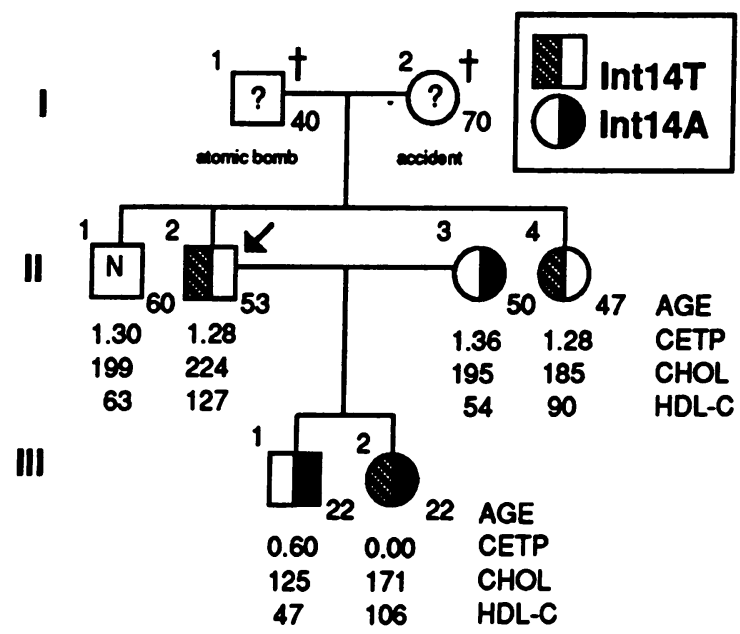

Pedigree of FHALP528 - KANAZAWA

II

III

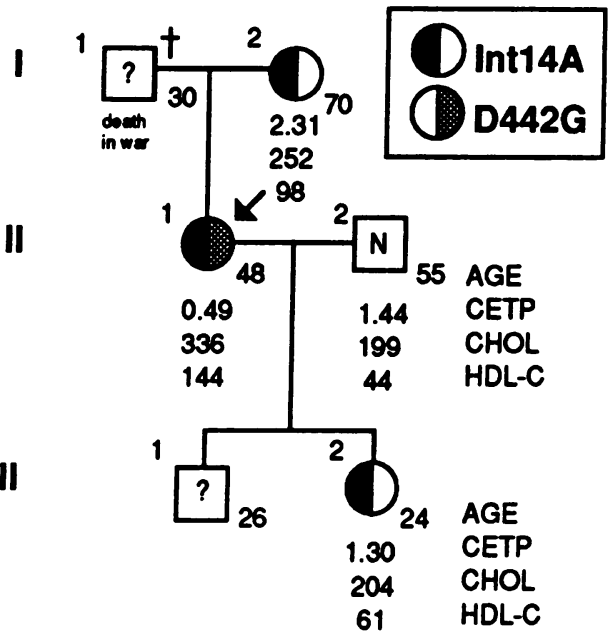

\section{Pedigree of FHALP277 - KANAZAWA}

\section{Pedigree of FHALP1084 - KOCHI}
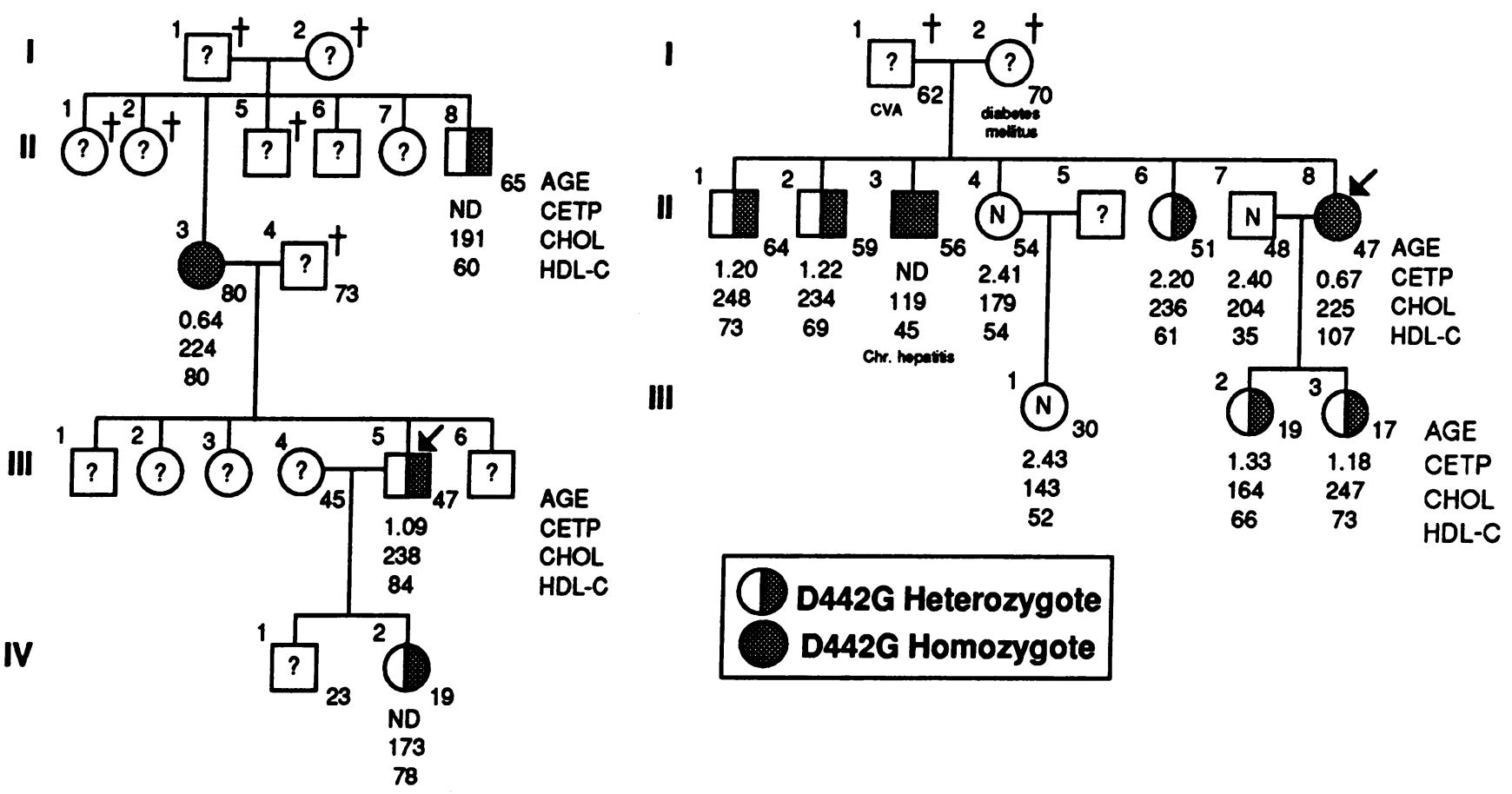

Figure 1. Pedigrees of CETP-deficient families caused by intron 14 splice donor site mutations and exon 15 missense mutation. The pedigree of kindred FHALP-464 shows the concurrent segregations of two different splice donor site mutations involving intron 14. The daughter (III-2) was a compound heterozygote with two different splice donor site mutations of Int14 A and Int14 T. Kindreds FHALP-277 and -1084 are families with a homozygote for D442G mutation. FHALP-528 has a compound heterozygote (II-1) of D442G and Int14 A mutations. Mildly to moderately increased HDL cholesterol levels tended to segregate with the D442G mutation as shown in kindreds FHALP-277 and -1084. HDL-C levels in D442G homozygotes were close or similar to those in heterozygotes in kindreds FHALP-277 and -1084. The proband (III-5) of kindred FHALP277 had vasospastic angina and xanthelasma. One obligate D442G heterozygote (I-1) in FHALP-1084 had history of cerebral vascular attack (CVA) of unknown cause. Arrows $(\leftarrow)$ indicate the proband of each family. Crosses represent deceased family members. N, normal CETP genotype; ND, not determined. Plasma CETP (mg/liter), serum cholesterol (mg/dl), and HDL-C, (mg/dl) are shown in each member.

the Int14 T using the PCR-based method (Fig. 3), but no others were found.

The effects of the D442G and Int14 T mutants on plasma CETP and lipoprotein levels are summarized in Table I. The lipid, apolipoprotein, and CETP levels associated with the different CETP genotypes are shown. The table includes subjects identified either in initial screening of subjects with HDL-C $\geq 60$ $\mathrm{mg} / \mathrm{dl}$ or in subsequent family studies of the probands. Unaffected 
normal allele

Leu Phe Asp lle

genomic DNA

sequence

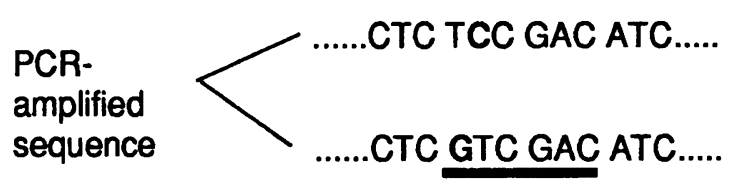

Sall

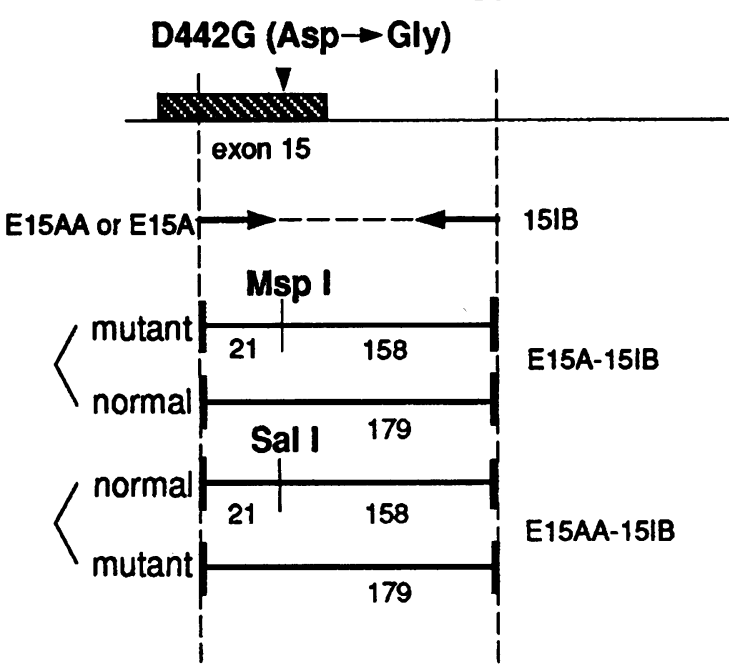

mutant allele

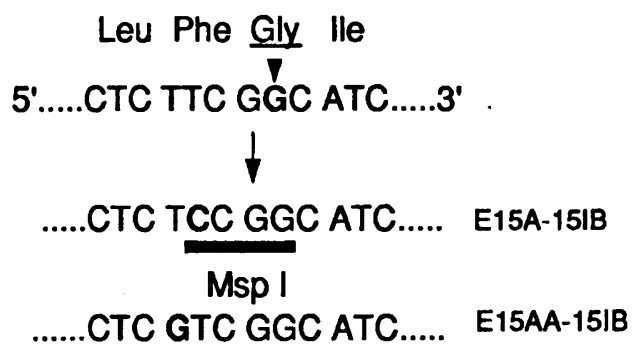

Figure 2. Rapid detection method for an exon 15 missense mutation (D442G) employing mutagenic primer-mediated restriction map modification. Using a mutagenic primer E15A and a reverse primer 15IB, gene amplification by PCR introduced an artificial MspI site in the PCR product only for the A-to-G allele (D442G). Digestion of the PCR products with MspI generates polymorphic restriction fragments of lengths of $179 \mathrm{bp}$ and/or $158 \mathrm{bp}$. The presence of the smaller fragment indicates the presense of the missense mutation. To confirm homozygosity or heterozygosity in the region of interest, the other PCR-based assay was also carried out with a mutagenic primer E15AA and the 15IB primer which create a Sall site in the PCR products for the normal allele at amino acid $442 \mathrm{~N}$, normal; He, heterozygote; Ho, homozygote; M, the molecular size marker of $\phi \chi 174$ / HaeIII digestion.

family members were first-degree relatives of the probands (i.e., parents, children, or siblings). Subjects with the Int14 A mutation were similar to those described in a previous report (20). Homozygotes for the D442G mutation had 57\% lower plasma CETP mass and 27\% lower CETP specific activities compared to unaffected family members. HDL-C levels in the homozygotes were moderately increased $(86 \pm 26 \mathrm{mg} / \mathrm{dl})$ compared to unaffected family members, but were not as high as in homozygotes with the Int14 A mutation $(158 \pm 35 \mathrm{mg} / \mathrm{dl}, P<0.001)$. Thus, the D442G mutant allele was only partially defective. Compared to unaffected family members, heterozygotes for the D442G mutation had $34 \%$ lower plasma CETP levels $(1.44 \pm 0.51 \mathrm{mg} /$ liter) and 55\% lower specific activities (both $P<0.001$ ). The differences in CETP specific activity comparing D442G heterozygotes and homozygotes were not significant. The Int14 A heterozygotes had similar reductions in plasma CETP concentration compared to the D442G heterozygotes, but had normal CETP specific activity. In the D442G heterozygotes, decreased plasma CETP levels and sp act led to a pronounced increase in HDL-C levels $(91 \pm 23$ $\mathrm{mg} / \mathrm{dl})$. The HDL-C levels in the D442G heterozygotes were significantly higher than those in the Int14 A heterozygotes $(69 \pm 15 \mathrm{mg} / \mathrm{dl}, P<0.001)$. Interestingly, the HDL-C levels in the $\mathrm{D} 442 \mathrm{G}$ heterozygotes were similar to those in the D442G homozygotes. Thus, the phenotypic effects of the D442G mutation on HDL are the same whether there are one or two mutant alleles involved, and greater than expected for one partially defective allele, suggesting that the $\mathrm{D} 442 \mathrm{G}$ allele is genetically dominant. In compound heterozygotes with the genotype Int14 A/ D442G, the mean HDL-C levels of $129 \mathrm{mg} / \mathrm{dl}$ were somewhat lower than those in the homozygotes for the Int14 A mutation, but higher than in heterozygotes with the Int14 A or D442G mutation. These results are compatible with low but detectable CETP activities in plasma of the compound heterozygote (Int14A/D442G).

The D442G homo- and heterozygotes showed increased apo A-I levels compared to unaffected family members as shown in Table II. Apo A-II levels were also increased in the D442G heterozygotes. However, the elevation in apo A-II levels was less remarkable so that the mass ratio of apo A-I/A-II in the D442G heterozygotes was increased as in homo- and heterozygotes with the Int14 A mutation. LDL cholesterol and apo B levels were not changed in partial CETP deficiency caused by the D442G homo- or heterozygotes, in contrast to decreased LDL cholesterol and apo B found in subjects with complete CETP deficiency (Tables I and II).

Frequencies of the two prevalent CETP gene mutations and 


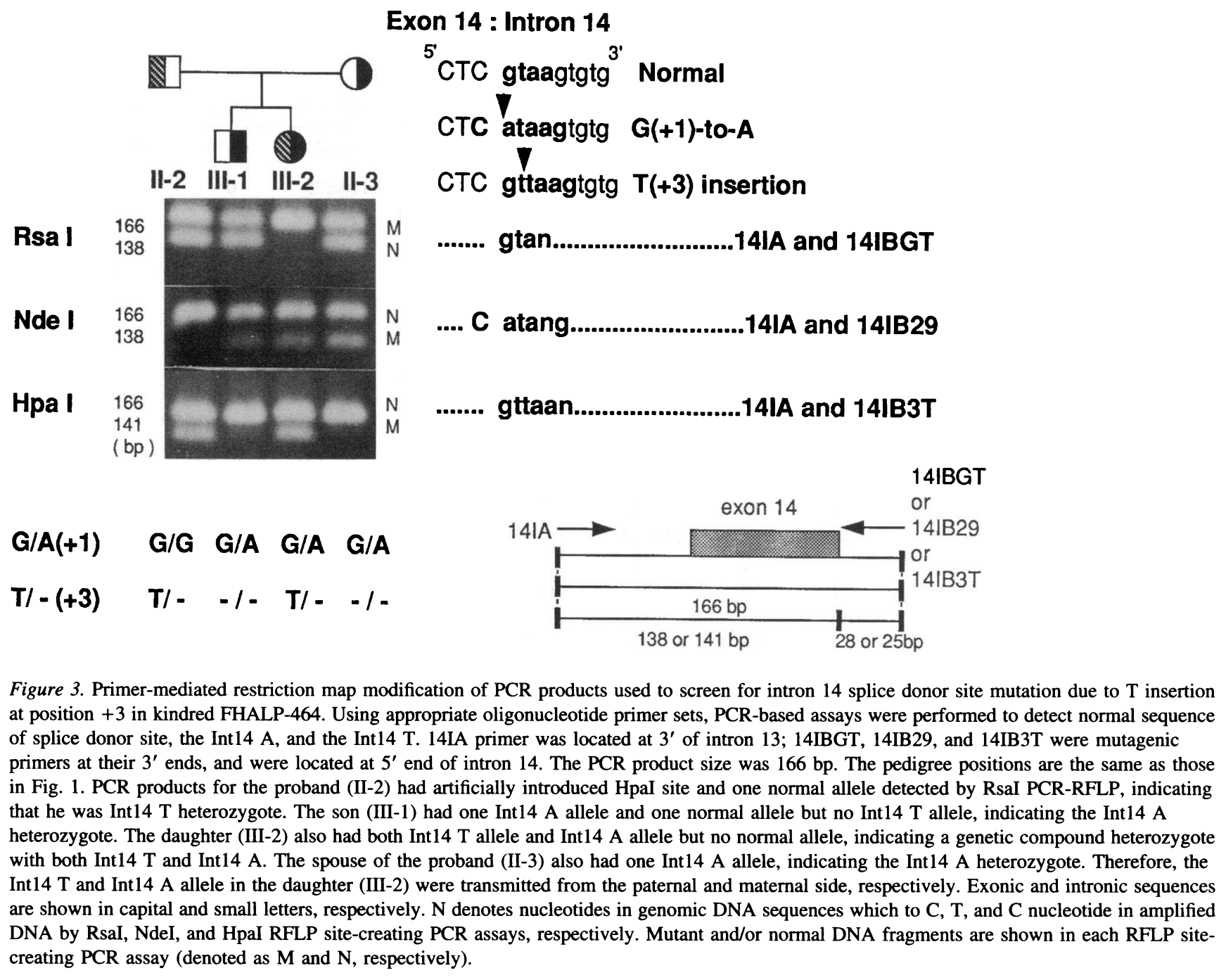

the distribution of HDL-C for each genotype are shown in Table III. This table includes only unrelated subjects derived from the screening study of subjects with HDL-C $\geq 60 \mathrm{mg} / \mathrm{dl}$. Both the Int14 $\mathrm{A}$ and $\mathrm{D} 442 \mathrm{G}$ mutations were extremely common in subjects with HDL-C $\geq 60 \mathrm{mg} / \mathrm{dl}$. The allele and heterozygote frequencies for both mutations tended to increase with increasing HDL-C up to $120 \mathrm{mg} / \mathrm{dl}$. Above this level, the Int14 A mutation became more frequent, mainly due to the high prevalence of the homozygotes, and the D442G mutation was less frequent. In the strata of HDL-C between 60 and $119 \mathrm{mg} / \mathrm{dl}$, the D442G mutation was two to four times more frequent than the Int14 A mutation, as reflected both in the overall mutant allele and heterozygote frequency.

To estimate the prevalence of the Int14 A or D442G mutations in a sample of general population, blood specimens of 236 healthy Japanese men were screened. The mean values of body mass index, serum cholesterol, TG, and HDL-C were $23.4 \pm 2.5 \mathrm{~kg} / \mathrm{m}^{2}$ (mean $\pm \mathrm{SD}$, range $13.2-36.0$ ), $193 \pm 31 \mathrm{mg} / \mathrm{dl}$ (range 116-269 mg/dl), 140 $103 \mathrm{mg} / \mathrm{dl}$ (range $26-763 \mathrm{mg} / \mathrm{dl}$ ), $49 \pm 13 \mathrm{mg} / \mathrm{dl}$ (range $24-95 \mathrm{mg} / \mathrm{dl}$ ), respectively. The frequency distribution of serum HDL-C values and the numbers of individuals with heterozygous CETP deficiency are shown in Fig. 4. Remarkably, 16 heterozygotes with the D442G mutation and 4 heterozygotes with the Int14 A mutation were detected. All of these heterozygotes had HDL-C values in the range $41-85 \mathrm{mg}$ / dl. The highest numbers of subjects with CETP gene mutations were found in the group with HDL-C $60-69 \mathrm{mg} / \mathrm{dl}$. The highest relative frequency $(56 \%)$ of heterozygous CETP deficiency was observed for HDL-C values of 70-79 mg/dl. Heterozygote frequencies with the Int14 A and D442G mutations were $1.7 \%$ (95\% CI, $0.1-3.8 \%$ ) and $6.8 \%$ (95\% CI, 4.1-9.9\%), respectively. Thus, combined gene frequency for CETP mutant alleles was $q=0.042$. The mean HDL-C levels in subjects with heterozygous CETP deficiency caused by either mutation $(n=20$, $62 \pm 12 \mathrm{mg} / \mathrm{dl}$ ) were significantly higher than those in subjects without CETP deficiency ( $n=216,48 \pm 12 \mathrm{mg} / \mathrm{dl}, P=0.0001)$. The number of subjects with the Int14 A mutation was too small to permit meaningful comparisons of HDL-C levels for the two different genotypes. Multiple regression analysis was performed by stepwise forward selection, using five variables (age, alcohol consumption, cigarette smoking, body mass index, and CETP genotype). All factors, except for age, were significant predictors of serum HDL-C levels in the sample of general Japanese men (Table IV). The adjusted $R^{2}$ values derived from the four variables was $28 \%$, and $18 \%$ after exclusion of the CETP genotype from variables. Furthermore, $10 \%$ of total phenotypic variance of $\mathrm{HDL}-\mathrm{C}$ was attributable to the presence of genetic CETP deficiency in the sample of general Japanese men 


\begin{tabular}{|c|c|c|c|c|c|c|c|c|c|}
\hline Mutations & $\begin{array}{l}\text { No. of } \\
\text { family }\end{array}$ & $\begin{array}{l}\text { No. of } \\
\text { subject } \\
(\mathrm{M} / \mathrm{F})\end{array}$ & Age* & Cholesterol** $^{* *}$ & $\mathrm{TG}^{* *}$ & LDL-C** & HDL-C*t & CETP* & Specific activity \\
\hline & & & $y r$ & $m g / d l$ & $m g / d l$ & $m g / d l$ & $m g / d l$ & mg/iter & nmol CE/ $/ \mu g$ CETP \\
\hline \multirow[t]{3}{*}{1 Int14A homozygote } & 15 & 22 & $55 \pm 10$ & $271 \pm 35$ & $118 \pm 88$ & $90 \pm 28$ & $158 \pm 35$ & 0 & NA \\
\hline & & $(12 / 10)$ & $35-68$ & $213-343$ & $61-429$ & $39-160$ & $98-230$ & 0 & \\
\hline & & & 22 & 22 & 22 & 22 & 22 & 22 & 22 \\
\hline \multirow[t]{3}{*}{2 Int14A heterozygote } & 12 & 28 & $50 \pm 20$ & $197 \pm 40$ & $95 \pm 46$ & $109 \pm 37$ & $69 \pm 15$ & $1.43 \pm 0.39$ & $176 \pm 147$ \\
\hline & & $(11 / 17)$ & $19-100$ & $117-273$ & $49-258$ & $51-191$ & $41-104$ & $0.60-2.31$ & $48-438$ \\
\hline & & & 28 & 28 & 28 & 28 & 28 & 28 & 4 \\
\hline \multirow[t]{3}{*}{3 D442G homozygote } & 4 & 4 & $62 \pm 14$ & $230 \pm 26$ & $58 \pm 19$ & $132 \pm 17$ & $86 \pm 26$ & $0.93 \pm 0.37$ & $110 \pm 86$ \\
\hline & & $(0 / 4)$ & $47-80$ & $213-268$ & $43-84$ & $109-148$ & $54-108$ & $0.64-1.44$ & $73-206$ \\
\hline & & & 4 & 4 & 4 & 4 & 4 & 4 & 4 \\
\hline \multirow[t]{3}{*}{4 D442G heterozygote } & 35 & 47 & $54 \pm 16$ & $220 \pm 43$ & $94 \pm 52$ & $110 \pm 37$ & $91 \pm 23$ & $1.44 \pm 0.51$ & $67 \pm 44$ \\
\hline & & $(24 / 23)$ & $17-81$ & $119-331$ & $34-281$ & $36-192$ & $45-141$ & $0.58-2.28$ & $17-231$ \\
\hline & & & 47 & 47 & 47 & 47 & 47 & 47 & 23 \\
\hline \multirow[t]{3}{*}{5 Int14A/D442G } & 2 & 2 & 55 & 295 & 77 & 152 & 129 & 0.86 & 154 \\
\hline & & $(0 / 2)$ & 48,61 & 254,336 & 51,102 & 131,172 & 113,144 & $0.49,1.22$ & 101,207 \\
\hline & & & 2 & 2 & 2 & 2 & 2 & 2 & 2 \\
\hline \multirow[t]{2}{*}{6 Int14A/Int14T } & 1 & 1 & 22 & 171 & 41 & 57 & 106 & 0 & NA \\
\hline & & $(0 / 1)$ & 1 & 1 & 1 & 1 & 1 & 1 & 1 \\
\hline \multirow[t]{3}{*}{7 Int14T heterozygote } & 1 & 2 & 50 & 205 & 78 & 81 & 109 & 1.28 & 178 \\
\hline & & $(1 / 1)$ & 47,53 & 185,224 & 49,107 & 74,87 & 90,127 & $1.28,1.28$ & 138,218 \\
\hline & & & 2 & 2 & 2 & 2 & 2 & 2 & 2 \\
\hline \multirow[t]{3}{*}{8 Unaffected family members } & 9 & 26 & $48 \pm 20$ & $189 \pm 37$ & $115 \pm 82$ & $116 \pm 36$ & $52 \pm 13$ & $2.17 \pm 0.52$ & $150 \pm 102$ \\
\hline & & $(10 / 16)$ & $14-77$ & $116-273$ & $39-362$ & $65-195$ & $33-82$ & $1.30-3.20$ & $60-351$ \\
\hline & & & 26 & 26 & 26 & 26 & 26 & 26 & 12 \\
\hline ANOVA, $F$-test & & $P$-value & 0.44 & 0.0001 & 0.49 & 0.04 & 0.0001 & 0.0001 & 0.0001 \\
\hline \multirow[t]{9}{*}{ Multiple comparison } & & 1 vs 2 & NS & $<0.001$ & NS & NS & $<0.001$ & $<0.001$ & NA \\
\hline & & 1 vs 3 & NS & NS & NS & $<0.05$ & $<0.001$ & $<0.001$ & NA \\
\hline & & 1 vs 8 & NS & $<0.001$ & NS & $<0.05$ & $<0.001$ & $<0.001$ & NA \\
\hline & & 2 vs 3 & NS & NS & NS & NS & NS & $<0.05$ & NS \\
\hline & & 2 vs 4 & NS & NS & NS & NS & $<0.001$ & NS & $<0.01$ \\
\hline & & 2 vs 8 & NS & NS & NS & NS & $<0.01$ & $<0.001$ & NS \\
\hline & & 3 vs 4 & NS & NS & NS & NS & NS & $<0.05$ & NS \\
\hline & & 3 vs 8 & NS & NS & NS & NS & $<0.01$ & $<0.001$ & NS \\
\hline & & 4 vs 8 & NS & $<0.01$ & NS & NS & $<0.001$ & $<0.001$ & $<0.001$ \\
\hline
\end{tabular}

* Age, lipid levels, CETP mass and sp act are mean \pm SD, ranges, and the numbers analyzed. ${ }^{\ddagger}$ To convert cholesterol and triglyceride values to $\mathrm{mmol} /$ liter, multiply by 0.02586 and 0.01129 , respectively. NS, not significant; NA, not applicapable.

in an analysis of the genetic variance based on gene frequencies and genotypic means.

\section{Discussion}

Genetic deficiency of CETP due to the Int14 A mutation is well established as a common cause of increased HDL in the Japanese. In the present study, two other CETP gene mutations have been characterized. One of these is a missense mutation, changing the codon of amino acid $\mathbf{4 4 2}$ from aspartate to glycine (D442G). The other is a novel splice donor site mutation due to a $\mathrm{T}$ insertion. Although there are distinctive differences in its phenotypic expression, like the Int14 A and Int14 $\mathrm{T}$, the D442G mutant has potent effects on plasma HDL. The development of PCR-based assays to detect these mutations allowed population studies to be conducted. Remarkably, the D442G mutation was found to be present in $18 \%$ of subjects with HDL$\mathrm{C} \geq 60 \mathrm{mg} / \mathrm{dl}$ and in $7 \%$ of a random sample of Japanese men. The D442G mutant thus appears to be about two to four times more frequent than the common Int14 A mutation. Although these data are based on small selected samples, genetic CETP deficiency is likely to be a major determinant of increased HDL$\mathrm{C}$ levels in the general Japanese population, with at least as large an impact on HDL-C levels as well-known environmental factors. The high prevalence of two common CETP gene mutations suggests a biological advantage for CETP deficiency, which could be related to several putative beneficial effects of high HDL levels.

The D442G mutation was so frequently found, both in subjects with increased HDL and in a general population sample, that it could be questioned whether this was a neutral polymorphism that would not affect CETP function or HDL levels. 
Table II. Apolipoprotein Levels in D442G, Intron 14 T Insertion, and Intron 14 G(+1)-to-A Mutants

\begin{tabular}{|c|c|c|c|c|c|c|c|c|}
\hline Mutations & & apo A-I & apo A-II & apo B & apo C-II & apo C-III & apo $E$ & $\begin{array}{c}\text { A-I/A-II } \\
\text { Ratio }\end{array}$ \\
\hline & & $m g / d l$ & $m g / d l$ & $m g / d l$ & $m g / d l$ & $m g / d l$ & $m g / d l$ & \\
\hline \multirow[t]{3}{*}{1 Int14A homozygote } & & $231 \pm 50$ & $45.2 \pm 13.2$ & $68 \pm 15$ & $10.1 \pm 7.3$ & $26.4 \pm 9.0$ & $12.4 \pm 4.8$ & $5.66 \pm 1.54$ \\
\hline & & $163-343$ & $24.2-72.0$ & $46-92$ & $4.5-31.8$ & $11.1-37.4$ & $5.8-23.6$ & $2.26-8.00$ \\
\hline & & 19 & 12 & 19 & 11 & 11 & 18 & 12 \\
\hline \multirow{3}{*}{\multicolumn{2}{|c|}{2 Int 14A heterozygote }} & $155 \pm 40$ & $32.4 \pm 5.7$ & $85 \pm 20$ & $4.4 \pm 1.8$ & $11.4 \pm 3.9$ & $5.0 \pm 2.4$ & $4.96 \pm 1.43$ \\
\hline & & $98-286$ & $23.0-43.0$ & $55-135$ & $1.6-7.2$ & $5.5-20.6$ & $3.2-6.7$ & $3.30-8.40$ \\
\hline & & 23 & 13 & 23 & 13 & 13 & 19 & 13 \\
\hline \multirow{3}{*}{\multicolumn{2}{|c|}{3 D442G homozygote }} & $175 \pm 24$ & $40.9 \pm 7.5$ & $85 \pm 14$ & $3.8 \pm 0.7$ & $9.4 \pm 2.1$ & $5.9 \pm 0.5$ & $4.31 \pm 0.27$ \\
\hline & & $147-192$ & $32.4-44.0$ & $75-101$ & $3.1-4.4$ & $7.0-10.9$ & $5.4-6.4$ & $4.02-4.54$ \\
\hline & & 3 & 3 & 3 & 3 & 3 & 3 & 3 \\
\hline \multirow{3}{*}{\multicolumn{2}{|c|}{4 D442G heterozygote }} & $178 \pm 30$ & $39.4 \pm 9.2$ & $89 \pm 24$ & $4.6 \pm 2.1$ & $13.0 \pm 4.7$ & $5.4 \pm 1.4$ & $4.82 \pm 1.25$ \\
\hline & & $118-228$ & $24.0-62.0$ & $48-130$ & $2.0-10.2$ & $6.4-24.3$ & $3.1-9.6$ & $2.77-8.68$ \\
\hline & & 44 & 34 & 44 & 34 & 34 & 44 & 34 \\
\hline \multirow{4}{*}{\multicolumn{2}{|c|}{5 Int14A/D442G }} & 189 & 20.0 & 83 & 4.7 & 11.7 & 8.9 & 9.96 \\
\hline & & & & & & & & 7.29 \\
\hline & & 175,202 & $16.0,24.0$ & 78,88 & $4.1,5.2$ & $11.0,12.3$ & $6.7,11.0$ & 12.63 \\
\hline & & 2 & 2 & 2 & 2 & 2 & 2 & 2 \\
\hline \multirow{2}{*}{\multicolumn{2}{|c|}{6 Int14A/Int14T }} & 171 & 28.0 & 40 & 2.0 & 10.2 & 9.7 & 6.11 \\
\hline & & 1 & 1 & 1 & 1 & 1 & 1 & 1 \\
\hline \multirow[t]{3}{*}{7 Int14T heterozygote } & & 206 & 36.0 & 95 & 4.3 & 12.5 & 6.8 & 6.50 \\
\hline & & 178,234 & & 84,106 & & & $5.1,8.4$ & \\
\hline & & 2 & 1 & 2 & 1 & 1 & 2 & 1 \\
\hline \multirow{3}{*}{\multicolumn{2}{|c|}{8 Unaffected family members }} & $122 \pm 23$ & $31.9 \pm 3.3$ & $93 \pm 24$ & $4.9 \pm 1.4$ & $10.4 \pm 4.4$ & $4.4 \pm 1.7$ & $3.79 \pm 0.56$ \\
\hline & & $65-168$ & $26.0-39.3$ & $58-143$ & $2.5-6.9$ & $6.0-19.3$ & $2.1-8.2$ & $2.79-4.44$ \\
\hline & & 22 & 14 & 22 & 14 & 14 & 22 & 14 \\
\hline ANOVA, $F$-test & $P$-value & 0.0001 & 0.002 & 0.003 & 0.0005 & 0.0001 & 0.0001 & 0.0078 \\
\hline \multirow[t]{9}{*}{ Multiple comparison } & 1 vs 2 & $<0.001$ & $<0.001$ & $<0.01$ & $<0.001$ & $<0.001$ & $<0.001$ & NS \\
\hline & 1 vs 3 & $<0.05$ & NS & NS & $<0.01$ & $<0.001$ & $<0.001$ & NS \\
\hline & 1 vs 8 & $<0.001$ & NS & $<0.001$ & $<0.001$ & $<0.001$ & $<0.001$ & $<0.001$ \\
\hline & 2 vs 3 & NS & NS & NS & NS & NS & NS & NS \\
\hline & 2 vs 4 & $<0.05$ & $<0.05$ & NS & NS & NS & NS & NS \\
\hline & 2 vs 8 & $<0.01$ & NS & NS & NS & NS & NS & $<0.05$ \\
\hline & 3 vs 4 & NS & NS & NS & NS & NS & NS & NS \\
\hline & 3 vs 8 & $<0.05$ & NS & NS & NS & NS & NS & NS \\
\hline & 4 vs 8 & $<0.001$ & $<0.01$ & NS & NS & NS & NS & $<0.01$ \\
\hline
\end{tabular}

Apo levels are mean $\pm S D$, ranges and the numbers analyzed. NS, not significant.

However, in kindreds, the mutation tended to segregate with high HDL-C levels (Fig. 1) and among subjects with increased HDL-C, the frequency of the mutation tended to increase within strata of increasing HDL-C levels (Table III). Also, subjects with the mutation had higher HDL-C values than those without the mutation in the general population sample (Fig. 4). Also, it is mechanistically plausible that the D442G mutant should increase HDL-C levels, since the mutant caused decreased plasma CETP concentration and specific activity, with proportionate effects on HDL-C (Table I). The D442G mutant is near a carboxy terminal region of CETP shown to be essential for function $(14,26)$. Finally, expression of the mutant cDNA in transfected cells showed both impaired secretion and sp act of the mutant CETP compared to the wild-type (23). Although the D442G mutant potently increased HDL levels, the magnitude of the effect was different in the different populations surveyed, possibly reflecting selection bias and/or the lower levels of HDL-C in an all-male population (Fig. 4). Initially, the D442G was reported to cause a very high HDL-C level as a single mutant allele (23). However, it is now evident that the D442G mutant typically results in moderate increases in HDL-C (Table I, Fig. 4).

Although the D442G allele was partially defective, several aspects of its phenotypic expression suggest genetic dominance. First, D442G heterozygotes and homozygotes had similar elevations in HDL-C. Second, the D442G heterozygotes had higher HDL-C values than the Int14 A heterozygotes (Table I). Thus, one allele with the D442G mutation has a larger effect on HDL$C$ than one null allele, even though the D442G mutant allele is not completely defective. These results indicate that the partially defective D442G allele tends to inhibit the expression of the wild-type allele, and are consistent with the dominant negative effects of the D442G cDNA in cell expression experiments (23). Although the mechanism of genetic dominance is poorly 
Table III. Frequencies of Two Prevalent CETP Gene Mutations in Unrelated Subjects with Increased HDL Cholesterol Levels

\begin{tabular}{|c|c|c|c|c|c|c|c|c|c|c|}
\hline \multirow{2}{*}{$\begin{array}{c}\text { HDL } \\
\text { cholesterol } \\
\text { group }\end{array}$} & \multirow{2}{*}{$\begin{array}{c}\text { No. of } \\
\text { individuals } \\
(\mathrm{M} / \mathrm{F})\end{array}$} & \multicolumn{2}{|c|}{ Heterozygote } & \multicolumn{2}{|c|}{ Homozygote } & \multirow{2}{*}{$\begin{array}{c}\text { Compound } \\
\text { heterozygote } \\
(\mathrm{M} / \mathrm{F})\end{array}$} & \multicolumn{2}{|c|}{$\begin{array}{l}\text { Frequency of Int14A } \\
\text { heterozygote and allele }\end{array}$} & \multicolumn{2}{|c|}{$\begin{array}{l}\text { Frequency of D442G } \\
\text { heterozygote and allele }\end{array}$} \\
\hline & & $\begin{array}{l}\text { Int 14A } \\
(\mathrm{M} / \mathrm{F})\end{array}$ & $\begin{array}{c}\text { D442G } \\
(\mathrm{M} / \mathrm{F})\end{array}$ & $\begin{array}{l}\text { Int14A } \\
(\mathrm{M} / \mathrm{F})\end{array}$ & $\begin{array}{c}\mathrm{D} 442 \mathrm{G} \\
(\mathrm{M} / \mathrm{F})\end{array}$ & & $\begin{array}{l}\%(\mathrm{No} . / \mathrm{N} \\
95 \% \mathrm{CI})\end{array}$ & $\begin{array}{c}\%(\mathrm{No} . / 2 \mathrm{~N}, \\
95 \% \mathrm{CI})\end{array}$ & $\begin{array}{l}\%(\mathrm{No} . / \mathrm{N} \\
95 \% \mathrm{CI})\end{array}$ & $\begin{array}{l}\%(\mathrm{No} . / 2 \mathrm{~N}, \\
95 \% \mathrm{CI})\end{array}$ \\
\hline \multicolumn{11}{|l|}{$m g / d l$} \\
\hline $60-79$ & $100(66 / 34)$ & $4(3 / 1)$ & $13(10 / 3)$ & 0 & 0 & 0 & $4.0(2.2-8.7)$ & $2.0(1.6-4.5)$ & $13.0(8.0-19.2)$ & $6.5(3.9-10.0)$ \\
\hline $80-99$ & $82(33 / 49)$ & $3(2 / 1)$ & $12(5 / 7)$ & $1(1 / 0)$ & $1(0 / 1)$ & 0 & $3.7(3.1-8.9)$ & $3.0(2.5-6.2)$ & $14.6(10.2-24.5)$ & $8.5(6.0-17.9)$ \\
\hline $100-119$ & $79(26 / 53)$ & $6(2 / 4)$ & $18(7 / 11)$ & 0 & $2(0 / 2)$ & *3 (0/3) & $7.6(6.6-16.8)$ & $5.7(4.9-9.5)$ & $22.8(15.2-30.4)$ & $15.2(10.9-20.1)$ \\
\hline $120-$ & $51(30 / 21)$ & $6(2 / 4)$ & $6(4 / 2)$ & $14(10 / 4)$ & 0 & ${ }^{ \pm} 2(0 / 2)$ & $11.8(10.9-22.1)$ & $35.3(28.3-42.2)$ & $11.8(10.9-22.1)$ & $7.8(4.0-13.4)$ \\
\hline Total & $312(155 / 157)$ & $19(9 / 10)$ & $49(26 / 23)$ & $15(11 / 4)$ & $3(0 / 3)$ & $5(0 / 5)$ & $6.1(5.4-8.7)$ & $8.7(6.9-10.7)$ & $15.7(12.5-19.2)$ & $9.5(7.7-11.5)$ \\
\hline
\end{tabular}

* The genotypes are two subjects with Int14 A/D442G and one with Int14 A/Int14 T. ${ }^{\ddagger}$ The genotypes are two subjects with Int14 A/D442G. 2N indicates the number of chromosomes analyzed. CI, confidence interval.

understood, it could reflect formation of multimeric species of CETP during cellular secretion and/or involvement of multimers in the lipid transfer process.

A novel intron 14 splice donor site mutation caused by a $T$ insertion at the +3 position relative to the exon 14/intron 14 boundary (Int14 $\mathrm{T}$ ) was also identified in this study. Plasma CETP mass and activity were undetectable in a subject who was a genetic compound heterozygote with both Int14 $\mathrm{T}$ and Int14 A mutations involving the same intron 14 splice donor. Therefore, the +3 position $\mathrm{T}$ insertion yields a null allele with no CETP produced (Fig. 1 kindred FHALP-464). In addition to the invariant GT dinucleotide located in the first two positions of a splice donor site, mutations at the +3 position also have been shown to cause defective alleles in several genetic disorders (34). Abnormal splicing in both mutants involving intron 14 is likely to result in a premature translation termination at the fourth codon encoded by exon 15 . This would occur either with exon 14 skipping or with activation of a predicted cryptic splice donor site located $10 \mathrm{nt}$ upstream from the exon 14/intron 14 junction.

The Int14 A mutation was initially found to be common among selected families with markedly increased HDL-C (20).

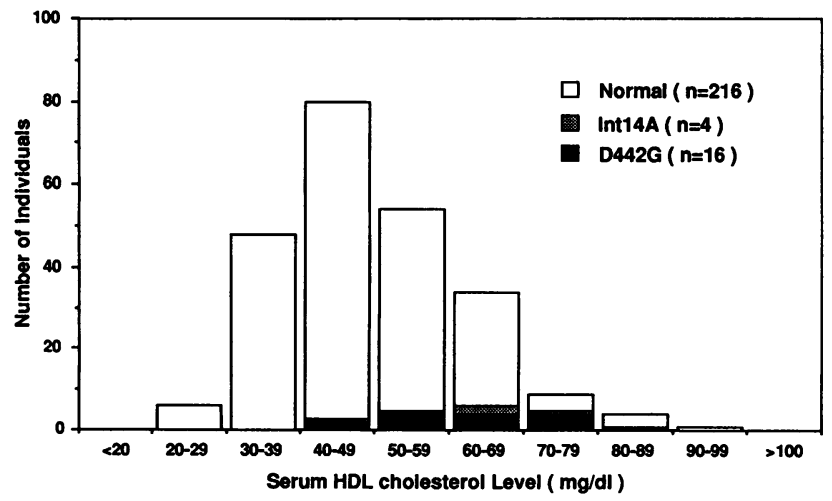

Figure 4. Frequencies of heterozygous CETP deficiency caused by two prevalent mutations in general Japanese men from Kanazawa district. The frequency of heterozygous CETP deficiency due to either the Int 14 A or D442G mutation was determined by PCR-based methods. In 236 healthy Japanese men, 4 Int 14 A heterozygotes and 16 D442G heterozygotes were identified. The heterozygote with either mutant were found in the range $41-85 \mathrm{mg} / \mathrm{dl}$.
More systematic studies revealed that this mutant was frequent in subjects with mildly to moderately increased HDL-C levels, and in as many as $1-2 \%$ of the general Japanese population (22). These results are comparable to those in the present study (Table III, Fig. 4). Although the Int14 A mutation is a common cause of hyperalphalipoproteinemia $(20,22)$, considered alone this mutation would not be sufficiently prevalent to influence the distribution of HDL-C levels in the general Japanese population. Unexpectedly, the frequency of the D442G mutation was found to be considerably higher than that of the Int14 A mutation (Table III, Fig. 4). Thus, the present study has established for the first time that genetic CETP deficiency, mainly due to the D442G mutant and to a lesser extent to the Int14 A mutant, is sufficiently common to influence HDL-C levels in the general Japanese population. The high prevalence of two different CETP mutations could suggest a biological advantage of CETP deficiency, related to putative beneficial effects of increased HDL levels.

HDL may have several different beneficial biological activities. As an antiatherogenic agent, HDL or its major protein (i.e., apo A-I) may facilitate cholesterol efflux from cells in atherosclerotic plaque $(3,4)$. HDL also promotes prostacyclin secretion and stabilization (35) and acts as a major carrier of lipid hydroperoxides, leading to less retention of oxidized lipids in LDL, consequently reducing its atherogenic potential (36).

Table IV. Multiple Regression Coefficients, F-values, and Adjusted $R^{2}$ for Serum HDL Cholesterol in a General Sample of Japanese Men

\begin{tabular}{lrrrrrr}
\hline & & & & & \multicolumn{2}{c}{ Adjusted $R^{2}$} \\
\cline { 5 - 7 } & \multicolumn{1}{c}{ Step variable } & Coefficient & SE & F-value & Total & Increment \\
\hline 1 & CETP genotype* & 0.281 & 0.050 & 31.5 & 0.094 & 0.094 \\
2 & Body mass index & -0.737 & 0.126 & 34.1 & 0.195 & 0.101 \\
3 & Cigarette smoking & -0.024 & 0.006 & 18.9 & 0.253 & 0.058 \\
4 & Alcohol consumption & 0.033 & 0.011 & 8.7 & 0.277 & 0.024
\end{tabular}

* Heterozygous CETP deficiency and normal CETP genotype are assigned a value of 1 and 0 , respectively. Intercept for multiple regression is 6.143. HDL cholesterol and body mass index are transformed to $\ln (\mathrm{x})$ of variables. Amounts of cigarettes and alcohol (units) are transformed to square root of variables. $n=236$. 
In addition, high HDL levels may protect against gram-negative bacteremia through the inactivation of bacterial lipopolysaccharide (37). Therefore, high HDL could provide a biological advantage in atherosclerotic or infectious diseases. Indeed, some epidemiological studies suggest that high HDL is associated with decreased total mortality from all causes, not just CHD $(38,39)$. The homozygous state of CETP deficiency does not produce obvious deleterious effects on health or reproduction. The high prevalence of the heterozygous CETP deficiency could be related to some biological advantage in CETP deficiency state or random genetic drift of defective alleles or both. However, there is currently no direct evidence of any biological advantage for CETP deficiency.

HDL consist of a heterogenous population of particles with varied apolipoprotein compositions; e.g., HDL with apo A-I only (Lp A-I), HDL with both apo A-I and A-II (LpA-I:AII). Recent studies in transgenic mice suggest that Lp A-I are antiatherogenic; Lp A-I:A-II, on the other hand, may suppress the antiatherogenic property of $\mathrm{Lp} \mathrm{A}-\mathrm{I}$ or even be actively proatherogenic $(40,41)$. However, such specific effects of HDL subpopulations have not been seen in epidemiological studies (42). In complete CETP deficiency, apo A-I and A-II were both increased, with a remarkable increase in the apo A-I: A-II ratio, perhaps indicating that antiatherogenic potential of HDL is stronger in CETP deficiency. In addition, 1 Int14 A homozygote (20), 3 Int14 A heterozygotes, and 4 D442G heterozygotes had evidence or history of cerebro vascular disease, and 2 Int14 A heterozygotes and 5 D442G heterozygotes had evidence or history of CHD including vasospastic angina in 22 Int14 A homozygotes, 4 D442G homozygotes, 5 compound heterozygotes, 57 Int14 A heterozygotes, 2 Int14 T heterozygotes, and 93 D442G heterozygotes including obligate heterozygotes. However, there is no evidence for atherosclerotic CHD in any cases of complete CETP deficiency. Taking high prevalences of heterozygous CETP deficiency in the general population into account, the prevalences of cardio- or cerebro-vascular diseases in CETP deficiency are not necessarily high. Taken together with recent studies of CETP transgenic mice (43), CETP could be an intrinsic proatherogenic protein under conditions of diets rich in cholesterol and saturated fat. However, CETP is involved in reverse cholesterol transport, which may have antiatherogenic effects as long as CE acceptor lipoproteins (i.e., chylomicron and VLDL remnants) are efficiently removed from the circulation (14). Although lower CETP levels in plasma could reduce atherogenic potential through decreasing CE contents in VLDL or chylomicron remnants as well as increasing HDL, it is not established whether decreased CETP levels are antiatherogenic in human. Population studies with a larger number of individuals are required to compare prevalences of $\mathrm{CHD}$, cerebrovascular disease, and other causes of morbidity and mortality in families with CETP deficiency with those in a control population.

The distribution of HDL-C levels in other ethnic groups (44) are similar to those in the Japanese (22), consistently showing skewness towards higher levels (Fig. 4). Furthermore, subjects with very high HDL-C levels are not rare in the Japanese (22) and other ethnic groups (45). However, genetic factors determining HDL-C levels in the general population have been poorly understood (6-11). In addition to genetic CETP deficiency, an apo C-III variant (46), hepatic lipase deficiency (47), a putative plasma CETP inhibitor (48), and increased apo A-I production rate (13) are candidate genetic causes of increased HDL-C levels. However, except for genetic CETP deficiency, the prevalence of these defects is unknown. It has been suggested that rare recessive genes probably do not explain a significant fraction of the phenotypic variation in HDL levels in the population $(6,7)$. Genetic CETP deficiency in other ethnic groups has not been documented. However, it is likely that more CETP mutants will be discovered in subjects with increased HDL both in the Japanese and other populations, because a variety of different molecular defects causing CETP deficiency have been reported; e.g., splicing defects, missense mutation, and nonsense mutation $(12,23,49)$. It is interesting to note that the independent, strong, inverse relation between HDL-C levels and incidence of CHD was initially established in men of Japanese descent living in Hawaii (50) and subsequently confirmed in most other ethnic groups (1). The incidence of CHD death in Japan is relatively low compared with those in other countries (51). Since the frequency of heterozygous CETP deficiency is shown to be as high as $9 \%$ in Japan, CETP deficiency could have a considerable impact on HDL-C levels in the population. It is likely that CETP deficiency is a major genetic cause of high HDL-C levels in the general Japanese population. Furthermore, it is possible that genetic CETP deficiency itself represents a negative $\mathrm{CHD}$ risk factor, contributing to a relatively low incidence of CHD in Japan.

\section{Acknowledgments}

We are indebted to Drs. H. Hashimoto, H. Yanase, N. Funaki, T. Wakasugi, and T. Takegoshi for referral of subjects with hyperalphalipoproteinemia, and to Ms. T. Misago for her excellent technical assistance.

This work was supported by a Scientific Research Grant (No. 04454235) from the Education Ministry of Japan for Dr. H. Mabuchi, and grants from National Institutes of Health (HL-21006, Arteriosclerosis Specialized Center of Research) for Dr. A. Tall.

\section{References}

1. Gordon, D. J., and B. M. Rifkind. 1989. High density lipoprotein-the clinical implications of recent studies. N. Engl. J. Med. 321:1311-1316.

2. Expert panel on detection, evaluation, and treatment of high blood cholesterol in adults. 1993. Summary of the second report of the National Cholesterol Education Program Expert Panel on detection, evaluation, and treatment of high blood cholesterol in adults (Adult Treatment Panel II). JAMA (J. Am. Med. Assoc.) 269:3015-3023.

3. Tall, A. R., and D. M. Small. 1978. Plasma high-density lipoproteins. $N$. Engl. J. Med. 299:1232-1236.

4. Tall, A. R. 1990. Plasma high density lipoproteins. Metabolism and relationship to atherogenesis. J. Clin. Invest. 86:379-384.

5. Patsch, J. R., S. Prasad, A. M. Gotto, Jr., and W. Patsch. 1987. High density lipoprotein ${ }_{2}$. Relationship of the plasma levels of this lipoprotein species to its composition, to the magnitude of postprandial lipemia, and to the activities of lipoprotein lipase and hepatic lipase. J. Clin. Invest. 80:341-347.

6. Breslow, J. L. 1989. Genetic basis of lipoprotein disorders. J. Clin. Invest. 84:373-380.

7. Breslow, J. L. 1989. Familial disorders of high density lipoprotein metabolism. In Metabolic Basis of Inherited Disease. 6th ed. C. R. Scriver, A. L. Beaudet W. S. Sly, and D. Valle, editors. McGraw-Hill Inc., New York. 1251-1266.

8. Amos, C. I., R. C. Elston, S. R. Srinivasan, A. F. Wilson, J. L. Cresanta, L. J. Ward, and G. S. Berenson. 1987. Linkage and segregation analyses of apolipoproteins A-I and B, and lipoprotein cholesterol levels in a large pedigree with excess coronary heart disease: the Bogalusa Heart Study. Genet. Epidemiol. 4:115-128.

9. Moll, P. P., V. V. Michels, W. H. Weidman, and B. A. Kottke. 1989. Genetic determination of plasma apolipoprotein A-I in a population-based sample. Am. J. Hum. Genet. 44:124-139.

10. Blangero, J., J. W. MacCluer, C. M. Kammerer, G. E. Mott, T. D. Dyer, and H. C. McGill, Jr. 1990. Genetic analysis of apolipoprotein A-I in two dietary environments. Am. J. Hum. Genet. 47:414-428.

11. Prenger, V. L., T. H. Beaty, and P. O. Kwiterovich. 1992. Genetic determination of high-density lipoprotein-cholesterol and apolipoprotein A-I plasma lev- 
els in a family study of cardiac catheterization patients. Am. J. Hum. Genet. 51:1047-1057.

12. Brown, M. L., A. Inazu, C. B. Hesler, L. B. Agellon, C. Mann, M. E. Whitlock, Y. L. Marcel, R. W. Milne, J. Koizumi, H. Mabuchi, et al. 1989 Molecular basis of lipid transfer protein deficiency in a family with increased high-density lipoproteins. Nature (Lond.). 342:448-451.

13. Rader, D. J., J. R. Schaefer, P. Lohse, K. Ikewaki, F. Thomas, W. A. Harris, L. A. Zech, C. A. Dujovne, and H. B. Brewer, Jr. 1993. Increased production of apolipoprotein A-I associated with elevated plasma levels of high density lipoproteins and apolipoprotein A-I in a patient with familial hyperalphalipoproteinemia. Metab. Clin. Exp. 42:1429-1434.

14. Tall, A. R. 1993. Plasma cholesteryl ester transfer protein. J. Lipid Res. 34:1255-1274.

15. Drayna, D., A. S. Jarnagin, J. McLean, W. Henzel, W. Kohr, C. Fielding, and R. Lawn. 1987. Cloning and sequencing of human cholesteryl ester transfer protein cDNA. Nature (Lond.). 327:632-634.

16. Agellon, L. B., E. M. Quinet, T. G. Gillette, D. T. Drayna, M. L. Brown, and A. R. Tall. 1990. Organization of the human cholesteryl ester transfer protein gene. Biochemistry. 29:1372-1376.

17. Callen, D. F., C. E. Hildebrand, and S. Reeders. 1992. Report of the second international workshop on human chromosome 16 mapping. Cytogenet. Cell Genet. 60:158-167.

18. Jiang, X. C., P. Moulin, E. M. Quinet, I. J. Goldberg, L. K. Yacoub, L. B. Agellon, D. Compton, R. Schnitzer-Polokoff, and A. R. Tall. 1991. Mammalian adipose tissue and muscle are major sources of lipid transfer mRNA. J. Biol. Chem. 266:4631-4639.

19. Inazu, A., E. M. Quinet, S. Wang, M. L. Brown, S. Stevenson, M. L. Barr, P. Moulin, and A. R. Tall. 1992. Alternative splicing of the mRNA encoding the human cholesteryl ester transfer protein. Biochemistry. 31:2352-2358.

20. Inazu, A., M. L. Brown, C. B. Hesler, L. B. Agellon, J. Koizumi, K. Takata, Y. Maruhama, H. Mabuchi, and A. R. Tall. 1990. Increased high-density lipoprotein levels caused by a common cholesteryl-ester transfer protein gene mutation. N. Engl. J. Med. 323:1234-1238.

21. Koizumi, J., A. Inazu, K. Yagi, I. Koizumi, Y. Uno, K. Kajinami, S Miyamoto, P. Moulin, A. R. Tall, H. Mabuchi, et al. 1991. Serum lipoprotein lipid concentration and composition in homozygous and heterozygous patients with cholesteryl ester transfer protein deficiency. Atherosclerosis. 90:189-196.

22. Inazu, A., J. Koizumi, T. Haraki, K. Yagi, T. Wakasugi, T. Takegoshi, H. Mabuchi, and R. Takeda. 1993. Rapid detection and prevalence of cholesteryl ester transfer protein deficiency caused by intron 14 splicing defect in hyperalphalipoproteinemia. Hum. Genet. 91:13-16.

23. Takahashi, K., X.-C. Jiang, N. Sakai, S. Yamashita, K. Hirano, H. Bujo, H. Yamazaki, J. Kusunoki, T. Miura, P. Kussie, et al. 1993. A missense mutation in the cholesteryl ester transfer protein gene with possible dominant effects on plasma high density lipoproteins. J. Clin. Invest. 92:2060-2064.

24. Orita, M., Y. Suzuki, T. Sekiya, and K. Hayashi. 1989. Rapid and sensitive detection of point mutations and DNA polymorphisms using the polymerase chain reaction. Genomics. 5:874-879.

25. Mohabeer, A. J., A. L. Hiti, and W. J. Martin. 1991. Non-radioactive single strand conformation polymorphism (SSCP) using the Pharmacia 'Phas System'. Nucleic Acids Res. 19:3154.

26. Wang, S., L. Deng, R. W. Milne, and A. R. Tall. 1992. Identification of a sequence within the C-terminal 26 amino acids of cholesteryl ester transfer protein responsible for binding a neutralizing monoclonal antibody and necessary for neutral lipid transfer activity. J. Biol. Chem. 267:17487-17490.

27. Inazu, A., J. Koizumi, H. Mabuchi, K. Kajinami, and R. Takeda. 1992 Enhanced cholesteryl ester transfer protein activities and abnormalities of high density lipoproteins in familial hypercholesterolemia. Horm. Metab. Res. 24:284288 .

28. Allain, C. C., L. S. Poon, C. S. G. Chan, W. Richmond, and P. C. Fu 1974. Enzymatic determination of total serum cholesterol. Clin. Chem. 20:470 475 .

29. Sugiura, M., T. Oikawa, K. Hirano, H. Maeda, H. Yoshimura, M. Sugiyama, and T. Kuratsu. 1977. A simple colorimetric method for determination of serum triglycerides with lipoprotein lipase and glycerol dehydrogenase. Clin Chim. Acta. 81:125-130.

30. Noma, A., Y. Hata, and Y. Goto. 1991. Quantitation of serum apolipoproteins A-I, A-II, B, C-II, C-III, E in healthy Japanese by turbidimetric immunoas- say: reference values and age- and sex-related differences. Clin. Chim. Acta. 199:147-158.

31. Friedewald, W. I., R. I. Levy, and D. S. Fredrickson. 1972. Estimation of the concentration of low density lipoprotein cholesterol in plasma without use of the preparative ultracentrifuge. Clin. Chem. 18:499-502.

32. Dawson-Saunders, B., and R. G. Trapp. 1990. Comparing three or more means. In Basic and Clinical Biostatistics. Appleton \& Lange, Norwalk, CT/San Mateo, CA. 124-141.

33. Khoury, M. J., T. H. Beaty, and B. H. Cohen. 1993. Genetic approach to familial aggregation. In Fundamentals of Genetic Epidemiology. Oxford University Press, Oxford UK. 200-283.

34. Cooper, D. N., and M. Krawczak. 1993. Single base-pair substitutions in human gene mRNA splice junctions and their phenotypic consequences. In Human Gene Mutation. BIOS Scientific Publishers Ltd., Oxford, UK. 239-260.

35. Fleisher, L. N., A. R. Tall, L. D. Witte, R. W. Miller, and P. J. Cannon. 1982. Stimulation of arterial endothelial cell prostacyclin synthesis by high density lipoproteins. J. Biol. Chem. 257:6653-6655.

36. Bowry, V. W., K. K. Stanley, and R. Stocker. 1992. High density lipoprotein is the major carrier of lipid hydroperoxides in human blood plasma from fasting donors. Proc. Natl. Acad. Sci. USA 89:10316-10320.

37. Ulevitch, R. J., A. R. Johnston, and D. B. Weinstein. 1979. New function for high density lipoproteins. Their participation in intravascular reactions of bacterial lipopolysaccharides. J. Clin. Invest. 64:1516-1524.

38. Goldbourt, U., E. Holtzman, and H. N. Newfeld. 1985. Total and high density lipoprotein cholesterol in the serum and risk of mortality. Br. Med. J. 290:1239-1243

39. Jacobs, D. R., I. L. Mebane, S. I. Bangdiwala, M. H. Criqui, and H. A. Tyroler. 1990. High density lipoprotein cholesterol as a predictor of cardiovascular disease mortality in men and women. The follow-up study of the lipid research clinics prevalence study. Am. J. Epidemiol. 131:32-47.

40. Schultz, J. R., J. G. Verstuyft, E. L. Gong, A. V. Nichols, and E. M. Rubin. 1993. Protein composition determines the anti-atherogenic properties of HDL in transgenic mice. Nature (Lond.). 365:762-764.

41. Warden, C. H., C. C. Hedrick, J. H. Qiao, L. W. Castellani, and A. J. Lusis. 1993. Atherosclerosis in transgenic mice overexpressing apolipoprotein AII. Science (Wash. DC). 261:469-472.

42. Stampfer, M. J., F. M. Sacks, S. Salvini, W. C. Willett, and C. H. Hennekens. 1991. A prospective study of cholesterol, apolipoproteins, and the risk of myocardial infarction. N. Engl. J. Med. 325:373-381.

43. Marotti, K. R., C. K. Castle, T. P. Boyle, A. H. Lin, R. W. Murray, and G. W. Melchior. 1993. Severe atherosclerosis in transgenic mice expressing simian cholesteryl ester transfer protein. Nature (Lond.). 364:73-75.

44. Castelli, W. P., G. R. Cooper, J. T. Doyle, M. Garcia-Palmieri, T. Gordon, C. Hames, S. B. Hulley, A. Kagan, M. Kuchmak, D. McGee, et al. 1977. Distribution of triglyceride and total, LDL and HDL cholesterol in several populations: a cooperative lipoprotein phenotyping study. J. Chronic Dis. 30:147-169.

45. Weitzman, J. B., and A. O. Vladutiu. 1992. Very high values of serum high-density lipoprotein cholesterol. Arch. Pathol. Lab. Med. 116:831-836.

46. von Eckardstein, A., H. Holz, M. Sandkamp, W. Weng, H. Funke, and G. Assmann. 1991. Apolipoprotein C-III(Lys ${ }_{58} \rightarrow$ Glu). Identification of an apolipoprotein C-III variant in a family with hyperalphalipoproteinemia. J. Clin. Invest. 87:1724-1731.

47. Hegele, R. A., J. A. Little, C. Vezina, G. F. Maguire, L. Tu, T. S. Wolever, D. J. A. Jenkins, and P. W. Connelly. 1993. Hepatic lipase deficiency. Clinical, biochemical, and molecular genetics characteristics. Arterioscler. Thromb. 13:720-728.

48. Kushwaha, R. S., S. Q. Hasan, H. C. McGill, Jr., G. S. Getz, R. G. Dunham, and P. Kanda. 1993. Characterization of cholesteryl ester transfer protein inhibitor from plasma of baboons (Papio sp.). J. Lipid Res. 34:1285-1297.

49. Gotoda, T., M. Kinoshita, H. Shimano, K. Harada, M. Shimada, J. Ohsuga, T. Teramoto, Y. Yazaki, and N. Yamada. 1993. Cholesteryl ester transfer protein deficiency caused by a nonsense mutation detected in the patient's macrophage mRNA. Biochem. Biophys. Res. Commun. 194:519-524.

50. Rhoads, G. G., C. L. Gulbransen, and A. Kagan. 1976. Serum lipoproteins and coronary heart disease in a population study of Hawaii Japanese men. $N$. Engl. J. Med. 294:293-298.

51. Simons, L. A. 1986. Interrelations of lipids and lipoproteins with coronary artery disease mortality in 19 countries. Am. J. Cardiol. 57:5G-10G. 